\title{
Die ontwikkeling van [j] in Afrikaans
}

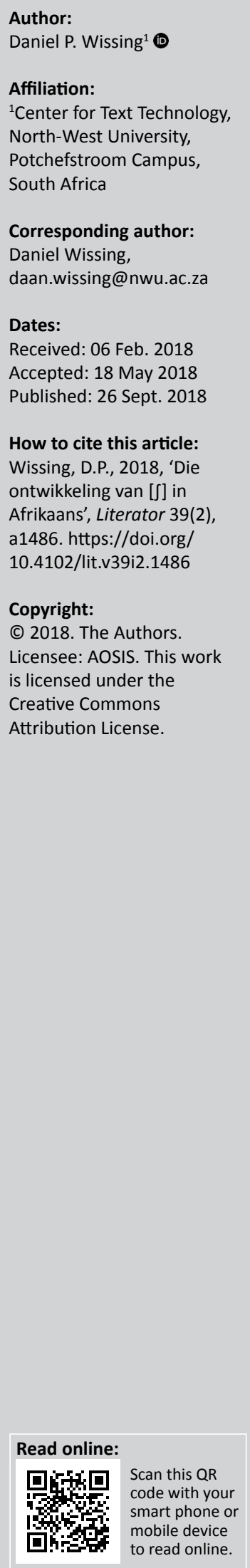

The development of [ $[\mathrm{d}$ in Afrikaans. This is a follow-up study on a seemingly recent development of the consonant system of Afrikaans that Wissing, Pienaar and Van Niekerk (2015) reported on. They show that the voiceless alveolar fricative /s / is produced as the [S], a voiceless postalveolar or alveopalatal fricative when immediately following the rhotic $/ \mathrm{r} /$, but as [s] in contexts other than this. To establish whether this phenomenon is characteristic of present-day Afrikaans in contrast to the pronunciation of previous generations, a survey was conducted in which the readings of news bulletins by two groups of radio presenters were analysed regarding their acoustic properties. These groups are representative of two generations of Afrikaans speakers, characterised as Oud [Old] and Jonk [Young]. Apart from the fact that the reading by Oud were recorded one to two decades ago (2000-2006), and those by Jonk during 2017, the average ages of these groups were at the time of recording 29 years for Jonk, and 50 years for Oud. A significant difference between the acoustic properties of the fricative /s/ following / r/ of these two groups was found. More specifically, Jonk, unlike Oud, clearly produced this phoneme as [S]. This shows that notable sound shifts might happen within a relatively short time span. The article is concluded by considering a possible explanation of this recent phenomenon within the realm of theories of internal sound change.

\section{Inleiding ${ }^{1}$}

Bekende fonologiese prosesse wat konsonante raak soos assimilasie (nasaalassimilasie, regressiewe en progressiewe assimilasie), of konsonantskrapping, is redelik goed in die meeste standaardhandboeke beskryf (vgl. Coetzee 1992; Combrink \& De Stadler 1987; De Villiers \& Ponelis 1987; Le Roux \& Pienaar 1927; Wissing 1971, 1984, 2017). Verwysings na relevante artikels word in al hierdie werke gevind. In onlangse publikasies word twee resente verskynsels van 'n ander aard behandel. Coetzee et al. (2018) wys op die veranderende aard van stemhebbende eksplosiewe /b, d/ wat in woordanlaut staan, en Wissing, Pienaar en Van Niekerk (2015) toon aan dat die stemlose alveolêre frikatief /s/ in toenemende mate progressief gewysig word tot [S] onder invloed van $/ \mathrm{r} / .^{2}$ Hierdie wysiging is assimilatories van aard; dit word soms laminasie genoem, hoewel waarskynlik ietwat onpresies, word hier met die term palatalisasie volstaan. ${ }^{3}$ Dit is veral, dog nie uitsluitend nie, die geval by jonger sprekers. Dit word in daardie werk gesuggereer dat ' $n$ mens hier waarskynlik met ' $n$ baie onlangse klankverandering te make het. Waarnemings van die uitspraak van 'n verskeidenheid sprekers oor 'n breë spektrum bevestig hierdie vermoede. Dit sluit veral jonger sprekers in soos studente en skoolleerders, radio-inbelprogramme, en veral jonger radiopersoonlikhede wat nuusberigte en weerberigte lees. Hierdie tendens is ook duidelik merkbaar by veral jonger predikers in kerkdiensuitsendings en dies meer. Die moontlikheid van so 'n klankverandering is die onderwerp van hierdie artikel.

Meer inligting is egter nodig oor die fonologiese en fonetiese eienskappe van [S].

In 'Die fonetiese eienskappe van $[\mathrm{s}]$ en $\left[\int\right]^{\prime}$, word op die fonetiese aspekte ingegaan. Fonologies gesien, is dit bekend dat /s/ geredelik in 'n proses van regressiewe assimilasie in vloeiende

1.Hierdie navorsing is gedeeltelik deur die Nasionale Navorsingstigting (NNS; Engels: NRF) van Suid-Afrika ondersteun. Opinies en gevolgtrekkings is die outeur s'n, en kan nie noodwendig aan die NRF toegeskryf word nie. Hierdie artikel is ook moontlik gemaak met die ondersteuning van die South African Centre for Digital Language Resources (SADiLaR). SADiLaR is ' $n$ navorsingsinfrastruktuur wat deur die Departement van Wetenskap en Tegnologie van die Suid-Afrikaanse Regering gestig is as deel van die South African Research Infrastructure Roadmap (SARIR).

2.Ek volg hier basies die konvensie dat simbole wat na foneme verwys in skuinsstrepe (/ /) geskryf word, en dié wat spesifiek na fone verwys in kantige hakies ([ ]). Dit is dikwels die geval dat dit nie duidelik is of, en wanneer' $n$ mens met die fonologiese of die fonetiese vorme te make het nie. Daarom word die skuinsstrepe hier as dekvorm gebruik, en slegs waar dit duidelik om allofone gaan - soos in die geval van [S], wat ook nie foneemstatus het nie soos wat wel die geval is met / r/. Hier word die dekvorm / r/ dus in alle gevalle die geval van [S], wat ook nie foneemstatus het nie soos wat wel die geval is met $/ \mathrm{r} /$. Hier word die dekvorm $/ \mathrm{r} /$ dus in alle gevalle
gebruik. ' $\mathrm{n}$ Soortgelyke benadering word vrylik in die internasionale fonologieliteratuur gevind soos byvoorbeeld in Chomsky en Halle gebruik. $n$ Soortgelyke benadering word
se The sound pattern of English (1968).

3.'n Anonieme keurder meen dat ' $n$ mens in die huidige geval eerder die term laminasie hiervoor moet gebruik as palatalisasie. Hy wys uit dat $[S]$ nie volledig palataal is nie. Dit sal egter finaal deur gebruikmaking van ultrasoniese ondersoeke uitgeklaar kan word. Die gebruik van die term palatalisasie word deur die term stemlose alveopalatale frikatief ondersteun, wat soms as fonetiese omskrywing hiervoor gebruik word. Die proses waaroor dit hier gaan, word in die Afrikaanse fonologiese tradisie palatalisasie genoem (vgl. byvoorbeeld De Villiers \& Ponelis 1987:174; Wissing 2017). 
omgangstaal as [S] uitgespreek word wanneer dit deur die palatale foneem $/ \mathrm{j} /$ gevolg word, byvoorbeeld in die frases

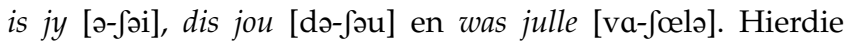
verskynsel kan as 'n vorm van koartikulasie gesien word, of regressiewe assimilasie, en meer bepaald palatalisasie. Dit word vreemd genoeg nie in Afrikaanse klankleerwerke genoem nie, byvoorbeeld dié van Coetzee (1981); Combrink en De Stadler (1987); De Bruto en Wissing (1974); De Villiers en Ponelis (1987); Le Roux en Pienaar (1927); Wissing (1971, 1984, 2014) - dit word wel in 'n hersiene hoofstuk deur Wissing uitgewys (in Carstens \& Bosman 2017). Sodanige assimilasie van konsonante in ander klankomgewings is welbekend in gevalle waar die stemlose velêre eksplosief /k/ veral voor die hoë voorvokale /i/ en /e/ palataliseer tot die stemlose palatale eksplosief [c] soos in [cis] </kis / kies en [ciəl] $</ \mathrm{kel} / \mathrm{keel}$. Om dieselfde rede word die stemlose velêre frikatief $/ \mathrm{x} / \mathrm{\prime}$ stemlose palatale frikatief [c] (vgl. [çit] $</$ xit/ giet, en [çiəl] < /xel/ geel). 'n Spesiale geval van regressiewe palatalisasie word in verkleiningsvorme /i/ gevind van woorde wat op die eksplosiefkonsonant $/ \mathrm{k} /$ eindig, ongeag die aard van die daaraan voorafgaande klank soos in [roci] rokkie < rok + DIM. of [bayci] bankie < bank + DIM. ${ }^{4}$

Wissing et al. (2015) toon aan dat /s/ in die volgende kontekste in [ $\left.\int\right]$ verander wanneer dit / $\mathrm{r} /$ volg:

- In kodaklusters (rs\#\#), byvoorbeeld in [barf] bars.

- In bimorfemiese konteks ( $\mathrm{r}+\mathrm{s})$, byvoorbeeld in [fuər/in] voorsien.

- In bisillabiese konteks (r\$s), byvoorbeeld in [fər]iəkər] verseker.

- In sinsverband (in frases) (r\#s), byvoorbeeld in [ə $\int$ riəts] is reeds.

Sodanige allofoniese wysiging kom die meeste voor in hierdie volgorde $(1>2>3>4)$.

\section{Die empiriese ondersoek}

In die hieropvolgende gedeeltes word toepaslike inligting verskaf van wat nodig is vir 'n begrip van die empiriese ondersoek en die resultate daarvan. Dit kom in die tweede hoofafdeling van die artikel aan die orde. 'n Kort uiteensetting van die fonetiese eienskappe - artikulatories én akoesties van die stemlose sibilante frikatiewe word verskaf, asook die metodes waarop akoestiese eienskappe van hierdie frikatiewe ontgin en beskryf word.

\section{Die fonetiese eienskappe van $[s]$ en $\left[\int\right]^{5}$ Artikulatoriese eienskappe}

Die stemlose alveolêre frikatief /s/ word met die punt of die blad van die tong teen of byna teen die alveolêre rif nét agter die boonste voortande geproduseer. [ $\left.\int\right]$, 'n frikatief

4.Hierdie /k/ word nie deur Le Roux en Pienaar in hulle uitspraakwoordeboek van Afrikaans sodanig getranskribeer nie, dog M. de Villiers (1961) maak 'n saak vir die transkribering van die / $\mathrm{k} /$ uit in onder meer rokkie (DIM van rok) as [roci], en nie transkribering van die $/ k /$ uit in ond
[roki nie]. Ek sluit my hierby aan.

5. Hierdie afdeling is deels op die ooreenstemmende afdeling in die artikel oor palatalisering in Afrikaans deur Wissing et al. (2015) gegrond. wat relatief min in Afrikaans voorkom, word as 'n stemlose palato-alveolêre, of ook postalveolêre of alveopalatale frikatief geklassifiseer. Tydens die produksie van [S] word die voorste gedeelte van die tong effens teruggetrek in die rigting van die palatum, wat dit 'n gepalataliseerde karakter gee. Figuur 1 is 'n grafiese voorstelling van hoe die tong ingespan word om [s] en [ $\left.\int\right]$ te produseer. Figuur 2 is foto's wat die lipstande tydens die uitspreek van hierdie frikatiewe toon.

Die opgeligte bolip by [ $\left.\int\right]$ is duidelik, en verleen daaraan 'n effens geronde karakter. Luister (Klankgreep 1) ook na die produksie van die frikatiewe [s] en [J] in die woorde bars ([bars]) en bars ([barf]).

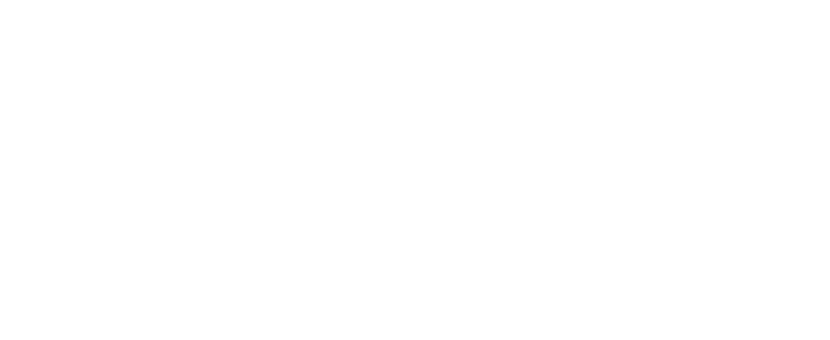

Bron: (C) Daniel P. Wissing. Opname gedoen Mei 2017 deur Daniel P. Wissing, stem van L. van den Bergh

KLANKGREEP 1: Luister na die produksie van die frikatiewe $[s]$ en $\left[\int\right]$ in die woorde bars ([bars]) en bars ([bar $]]$ ).

\section{Akoestiese eienskappe}

Die vorm van die mondholte tydens die produsering van klanke is bepalend vir die akoestiese kenmerke daarvan. Die voorste mondholte (in Figuur 1 aangedui as die sublinguale holte) van $\left[\int\right]$ is merkbaar groter as dié van [s], wat saam met die betrokke lipstand verantwoordelik is vir hierdie verskil. Spektrale analises (vgl. Figuur 4) wys op 'n relatief duidelike hoër konsentrasie van energie in die hoër frekwensie-areas van [s] vergeleke by dié van [J], wat die persepsie van 'n skerper frikatief in die geval van [s] veroorsaak.

Die energieverspreiding in die spektra van frikatiewe word gewoonlik in terme van spektrale momente uitgedruk.

Spektrale momente: Die spektra van aperiodiese konsonante word gewoonlik deur middel van die Fast Fourier

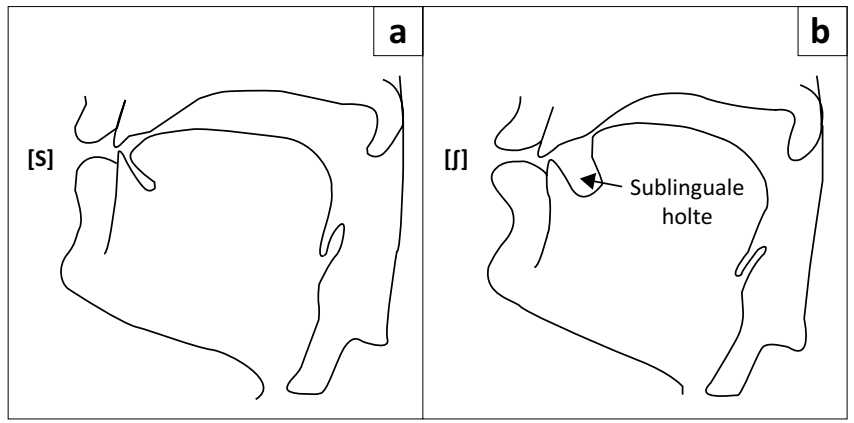

Bron: Skets is op dié van Johnson gegrond: http://linguistics.berkeley.edu/ kjohnson/ling110/ Lecture_Slides/8_Acoustics/fricative_acoustics.pdf

FIGUUR 1: Tongstand tydens die artikulasie van (a) [s] en (b) [J].

6.My dank en groot waardering aan Wikus, wat nie net hierdie foto geneem het nie, maar ook sy groot kennis van tegnologiese hulpmiddels geredelik beskikbaar gestel het. 


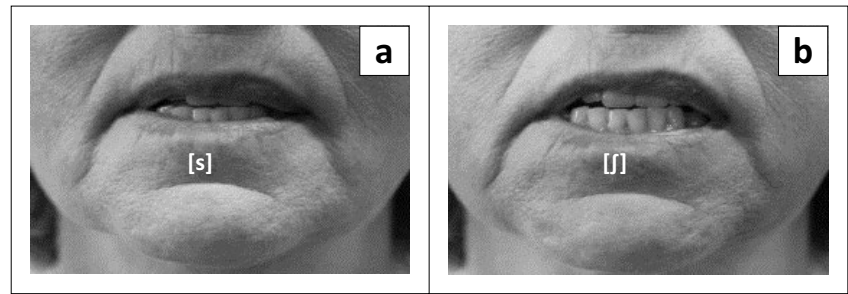

Bron: Foto met vergunning van Wikus Pienaar ${ }^{6}$ van CtexT

FIGUUR 2: Lipstand tydens die artikulasie van (a) [s] en (b) [ $\left.\int\right]$.

Transform (FFT)-metode bereken, op grond waarvan die gravitasiemiddelpunt $\left(\mathrm{CoG}^{7}\right)$ daarvan bereken word. Hierdie spektrale parameter verteenwoordig die gemiddelde frekwensie van die betrokke spektrale gedeelte. Die resultaat hiervan word in 'n enkele CoG-waarde uitgedruk, en wel in terme van Hertz. Sodanige CoG-waarde korreleer goed met die persepsie van die betrokke klank. Soos hierbo uitgewys is, klink [s]-fone tipies skerper as [S]-klanke, hoofsaaklik vanweë hulle distinktief hoër CoG-waardes. Ander momente wat soms in soortgelyke studies gebruik word, is Standaardafwyking, Skeefheid en Kurtose. CoG word ook in studies soos hierdie oorwegend as die beste, mees robuuste onderskeier genoem tussen spesifiek die sibilante [s] en [ $\left.\int\right]$. Op grond hiervan, en ook op grond van die resultate wat in Wissing et al. (2015) verkry is, is CoG ook as die enigste moment in die huidige ondersoek gebruik. Skeefheid word ook soms aangehaal as van waarde by die onderskeiding tussen die stemlose sibilantfrikatiewe [s] en [J] (Bekker 2007), maar die presiese karakteristieke aard daarvan wissel sodanig dat dit nie in 'n oorsigstudie soos hierdie nodig of verstandig is om te gebruik nie. Jongman et al. (2000) wys byvoorbeeld op kontrasterende bevindings ten opsigte van /s/ en /f/ wat hierdie spektrale moment betref, wat ook moontlik na [s] en [S] oorgedra kan word in die geval van Afrikaans. Wissing et al. (2015) verwys ook na ander meer resente literatuur in hierdie verband.

Hierdie studie is dus tot CoG beperk. 'n Enkele opmerking word wel gemaak oor die spesifieke wyse waarop Skeefheid in die geval van Afrikaans manifesteer.

In die volgende afdeling word meer besonderhede verskaf aangaande die wyse waarop CoG-waardes vasgestel word, en ook oor die interpretasie daarvan, onder meer oor hoe spektrogramme van die betrokke frikatiewe geïnterpreteer moet word.

\section{Analisemetodes}

Ortografiese transkripsies van 'n gegewe opname (in hierdie geval van die lees van nuusbulletins) is 'n noodsaaklike voorprosesseringsproses ten einde die CoG-waardes van die betrokke frikatiewe vas te stel. Hierdie transkripsies word eerstens na hulle te verwagte fonetiese vorms omgeskakel deur van grafeem-tot-foneem-omsettingsreëls gebruik te maak. Die Default\&Refine-algoritme (Davel \& Barnard 2008) gravity]; so ook in hierdie artikel gebruik, al is die teks in Afrikaans geskryf.

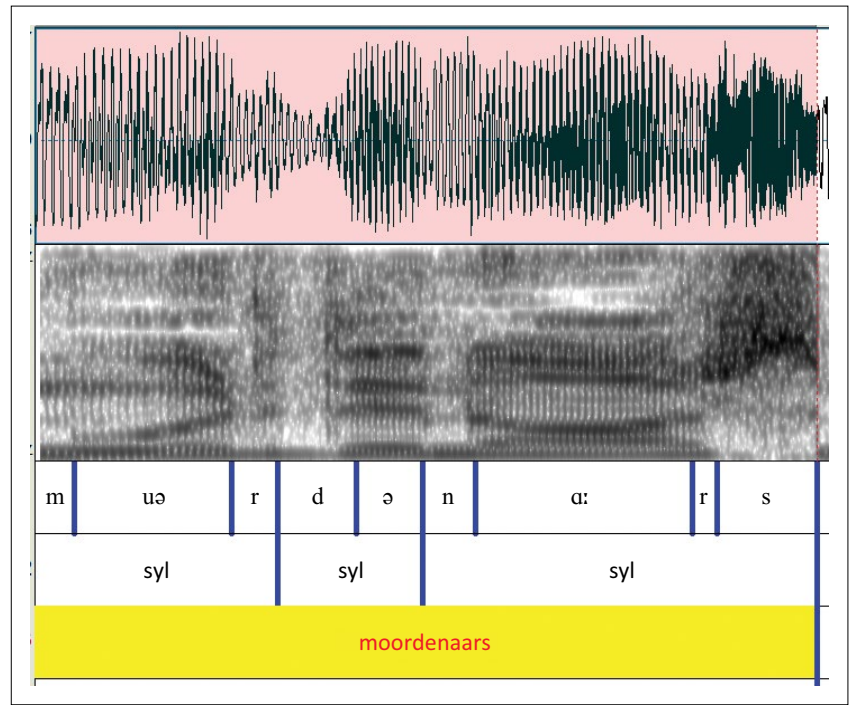

Die klankgolfvorm verskyn in die boonste venster, die spektrogram daarvan in die venster direk daaronder. In die drie teksvensters (textgrids) word die nege individuele klanke tussen blou grense aangedui, asook die drie sillabes (syl) wat daarmee geassosieer word. Die woord self staan in die onderste venster.

FIGUUR 3: Resultaat (in Praat) van outomatiese belynings, segmenterings en annoterings van die woord 'moordenaar', soos in die teks beskryf is.

is hier gebruik. 'n Uitspraakwoordeboek (Davel \& De Wet 2010) vorm deel van hierdie proses. Vervolgens is statistiese modelle bepaal, gegewe die verwagte fonetiese opeenvolgings en die daarmee geassosieerde klankopnames soos in Van Niekerk en Barnard (2009) beskryf is. Hierdie modelle is gebruik ter vasstelling van die belyning tussen die foonsekwensies aan die een kant, en die klankopnames aan die ander kant. Die finale resultaat van hierdie proses is gesegmenteerde individuele klankeenhede, ${ }^{8}$ afgegrens tot op die naaste $5 \mathrm{~ms}$. Hierdie klankeenhede word in 'n aparte venster tydens 'n gepaardgaande annoteringsfase benoem. Sodanige gesegmenteerde en geannoteerde klanke kan visueel en ouditief in Praat (Boersma \& Weenink 2015) geïnspekteer word, en indien nodig, handmatig verstel word. Figuur 3 is 'n voorstelling hiervan; Figuur 4 wys meer spesifiek op die spektrale eienskappe van die fone [s] en [S]. Spektrale inligting is ook hierop aangebring.

In die volgende afdeling ('Die voorondersoek') word eerstens van 'n voorondersoek na die uitspraak van 'n groter groep Radio Sonder Grense (RSG)-nuuslesers verslag gegee voordat die aandag op die hoofondersoek (sien 'Die hoofondersoek') ten opsigte van die produksies van /s/ as [s] en [ $\left.\int\right]$ toegespits word soos dit hierbo uiteengesit is.

\section{Die voorondersoek}

'n Eerste ondersoek met die oog op 'n algemene oorsig is na die produksie van alle/s/-foneme in 'n beskikbare spraakdatastel gedoen. Hierdie stel bestaan uit nuusbulletins soos deur 14 aanbieders van die nasionale RSG-radiostasie gelees. Die geolektiese agtergrond van die sprekers is onbekend, sodat geen gevolgtrekking ten opsigte van die verspreiding gemaak kan word van die verskynsel van fonemies. So byvoorbeeld word die foneemvokaal /o/ as [uə] getranskribeer. 


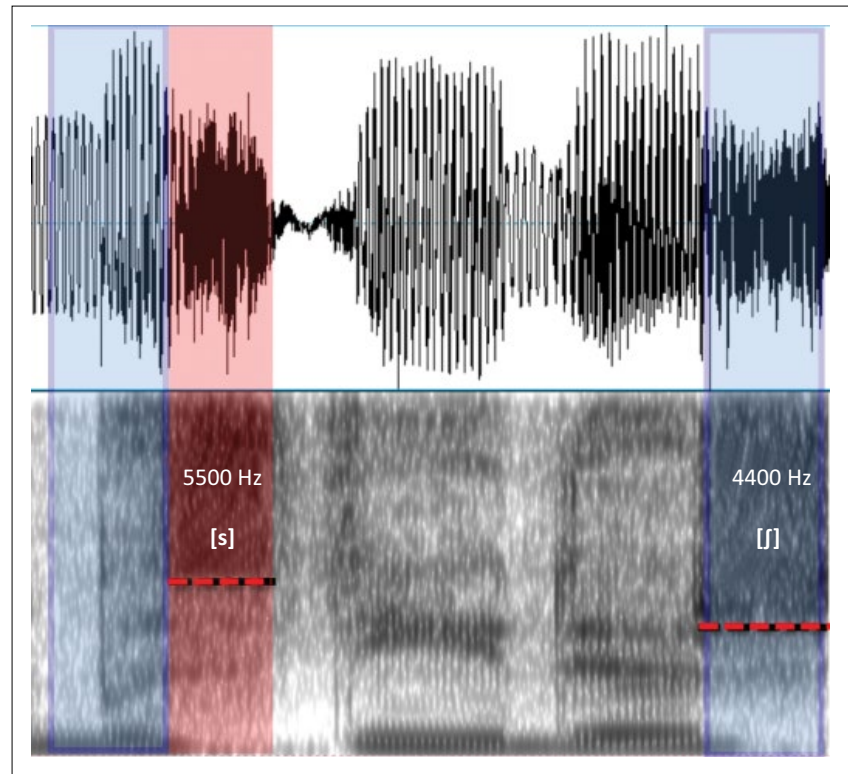

Nota: Die groter konsentrasie van energie (donkerder area in die spektrogram) in die geval van $[s]$ is duidelik te sien wanneer dit met die ooreenstemmende gedeelte by $[\delta]$ vergelyk word.

FIGUUR 4: Ossilogram en spektrogram van die woord 'bestuurders'. Die twee /s/-klanke is ingekleur en gemerk, asook van hulle gravitasiemiddelpuntwaardes voorsien.

palatalisasie wat hier ondersoek word nie. Nege van hierdie lesers is vroulik, waarvan vier se opnames gedurende die tydperk 2000-2006 (Oud) gemaak is; die ander vyf s' $\mathrm{n}$ is in 2017 (Jonk) gemaak. Voorts word deurgaans na dié twee groepe as Oud en Jonk verwys ${ }^{9}$. Drie van die vyf manlike sprekers se opnames val onder Oud, die ander twee onder Jonk. Uit die groottotaal van 1923 gevalle (waarvan 11 ongeldig was; 1912 geldig) is 903 dié van die /s/-foneem in isolasie (soos in mes; dus [s]), en die res (1020) met /r/ direk daaraan voorafgaande in woordeinde soos in leiers). Hierdie /s/-medeklinker is na alle waarskynlikheid meestal as [S] geproduseer, maar inspeksie van CoG-waardes hiervan sal dit kan bevestig (of nie). Hierdie waardes word in Tabel 1 weergegee.

Die /s/-foneem met / r/ direk voorafgaande word hier en elders, gemakshalwe reeds as [S] getranskribeer. Die d-waarde ${ }^{10}$ van 0.40 wys op 'n prakties matig beduidende verskil tussen die akoestiese metings van die twee tipes /s/. Hieruit kan minstens afgelei word dat daar 'n fonetiese verskil deur die groep as geheel gemaak word, en dat dit op 'n palatalisering van die /rs/-geval kan dui. Hierdie afleiding word grootliks deur resultate van byvoorbeeld Kwakkel (2008) ondersteun in die geval van vroulike Nederlandssprekendes, naamlik $3425 \mathrm{~Hz}$ in die geval van [J], en $5410 \mathrm{~Hz}$ vir [s]; 'n ietwat

9.Let op dat die 2017-groep hoofsaaklik uit jonger sprekers bestaan (waarskynlik gemiddeld 30-40 jaar oud). Daarenteen was die eerste groep tydens die opnames van 2000-2006 kennelik véél ouer (waarskynlik ouer as 50 jaar gemiddeld). Vir die doeleindes van vergelyking tussen die twee groepe kan ' $n$ ouderdomsgaping van ongeveer 40 jaar dus veronderstel word.

10.Effekgrootte-indekse word in terme van d-waardes uitgedruk. In die geval van CoG's word d's deur die volgende formule bereken: Die verskil tussen twee CoGwaardes, gedeel deur die grootste standaardafwyking daarvan. Hierdie indeks word by die bepaling van die praktiese betekenisvolheid van die verskille tussen twee metings gebruik. $d<0.20$ stel geen betekenisvolle effek voor; $d=0.20-0.49$ ' $n$ klein metings gebruik. $d<0.20$ stel geen betekenisvolle effek voor; $d=0.20-0.49$ ' $n$ klein
effek; $d=0.50-0.79$ ' $n$ matige effek, en $d=0.80$ en groter ' $n$ groot effek. In die hieropvolgende teks word die spesifikasie 'prakties(e)' deurgaans geïmpliseer. Praktiese betekenisvolheid staan teenoor statistiese betekenisvolheid, wat tipies op Praktiese betekenisvolheid staan teenoor statistiese betekenisvolheid, wat tipies op
p-waardes - tipies in parametriese statistiek gebruik word. Cohen (1988) moet hierby gelees word.
TABEL 1: Swaartepuntgemiddeldes (gravitasiemiddelpunt-waardes, uitgedruk in Hertz), van 'n groep Radio Sonder Grense-nuuslesers (sien teks vir uiteensetting).

\begin{tabular}{lcccc}
\hline Klank & Gem. CoG & Gemete gevalle & Std.afw. CoG & $\begin{array}{c}d \text {-waarde: } \\
\text { verskil /s/ en /rs/ }\end{array}$ \\
\hline$[S]$ & 3854 & 1017 & 762 & 0.40 \\
{$[\mathrm{~s}]$} & 4286 & 895 & 1076 & - \\
\hline
\end{tabular}

Gem., gemiddeld; Std. afw., standaardafwyking, CoG, gravitasiemiddelpunt.

TABEL 2: Swaartepuntgemiddeldes (gravitasiemiddelpunt-waardes, uitgedruk in Hertz van twee stelle Radio Sonder Grense-nuuslesings tydens die periodes 2000-2006 en 2017)

\begin{tabular}{lccccc}
\hline Ouderdomskategorie & Frikatief & $\begin{array}{c}\text { Gem. } \\
\text { CoG }\end{array}$ & $\begin{array}{c}\text { Gemete } \\
\text { gevalle }\end{array}$ & $\begin{array}{c}\text { Std.afw. } \\
\text { CoG }\end{array}$ & $\boldsymbol{d}$-waardes \\
\hline Oud & {$[\mathrm{s}]$} & 4117 & 536 & 1003 & 0.17 \\
& {$[\mathrm{~S}]$} & 3947 & 606 & 851 & - \\
Jonk & {$[\mathrm{s}]$} & 4539 & 359 & 1131 & 0.73 \\
& {$[\mathrm{~S}]$} & 3716 & 411 & 582 & - \\
\hline
\end{tabular}

Gem., gemiddeld; Std. afw., standaardafwyking, CoG, gravitasiemiddelpunt.

groter verskil as in die geval van Afrikaans. Vorige ondersoeke, genoem in die inleiding, laat egter wel die moontlikheid oop dat die verskil groter by Jonk as by Oud kan wees, gegewe die feit dat daar 'n tydperk van 11-17 jaar tussen die twee opnameperiodes verloop het. Voorts speel die ouderdomsverskille tusen die lede van die twee opnamegroepe ook hier 'n bydraende rol. Die gegewens van Tabel 2 versterk hierdie verwagting.

Die $d$-waardes van hierdie twee groepe verskil duidelik van mekaar: Oud se $d=0.17$ druk 'n onbeduidende verskil tussen die CoG's van die twee klanke uit, terwyl dié van Jonk $(d=0.73)$ die vlak van 'n prakties hoogs beduidende verskil benader (sien voetnoot 10 vir die betekenis van hierdie tipe verskil).

Hierdie bevindings word voorts in die volgende afdeling in ' $n$ meer omvattende en meer presies opgesette ondersoek opgevolg.

\section{Die hoofondersoek}

In hierdie ondersoek is die uitspraak van agt vroulike nuuslesers geanaliseer. Dit is geneem uit die groot groep gevalle $(N=1912)$ van die voorgaande afdeling; hier vier elk uit Oud en Jonk $(N=971)$. Die besluit om slegs op vroulike lesers te fokus, is eerstens op praktiese oorwegings gegrond, hoofsaaklik omdat Jonk in daardie groep grotendeels uit vroue bestaan - daar is slegs twéé manlike persone in daardie groep, waarvan bowendien van slegs één voldoende opnames beskikbaar was. Tweedens optimaliseer dit 'n vergelyking met die bevindings van die studie van Wissing et al. (2015) op gepalataliseerde /s/'e wat ook slegs vrouesprekers omvat, en derdens is dit 'n bekende feit dat vroulike taalgebruikers gewoonlik op die voorpunt van taalverandering is (Labov 2001).

In Tabel 3 word die betrokke gegewens van die twee subgroepe vroulike lesers weergegee. Die verskil tussen die twee groepe word presies uitgedruk in terme van die $d$-waardes (resp. 0.09 teenoor 1.35). Wat meer is: $d=0.09$ beteken 'n totale afwesigheid van enige betekenisvolle verskil tussen die akoestiese eienskappe betreffende CoG tussen die 
TABEL 3: Swaartepuntgemiddeldes (gravitasiemiddelpunt-waardes, uitgedruk in Hertz van twee stelle vroulike Radio Sonder Grense-nuuslesers tydens die periodes 2000-2006 en 2017.

\begin{tabular}{lccccc}
\hline Ouderdomskategorie & Frikatief & Gem. CoG & $\begin{array}{c}\text { Gemete } \\
\text { gevalle }\end{array}$ & $\begin{array}{c}\text { Std.afw. } \\
\text { CoG }\end{array}$ & $\boldsymbol{d}$-waardes \\
\hline Oud & {$[\mathrm{s}]$} & 4102 & 231 & 615 & 0.09 \\
& {$[\mathrm{~s}]$} & 4196 & 354 & 1037 & - \\
Jonk & {$[\mathrm{S}]$} & 3819 & 195 & 482 & 1.35 \\
& {$[\mathrm{~s}]$} & 5083 & 191 & 938 & - \\
\hline
\end{tabular}

Gem., gemiddeld; Std. afw., standaardafwyking, CoG, gravitasiemiddelpunt.

twee realisasies van /s/. Daarenteen is hierdie verskil by die Jonk-groep hoogs betekenisvol $(d>0.8)$. 'n Mens sou dus met vertroue kon stel dat sprekers met d-waardes van hoër as 1.0, soos hier die geval is met Jonk, as Palataliseerders getipeer kan word, terwyl Oud met d's selfs laer as 0.10 sonder twyfel Nonpalataliseerders genoem kan word.

Die verskille tussen die twee groepe word ook in elkeen van die CoG-waardes van die individuele lesers van elke groep gevind. Figuur 5 is 'n grafiese voorstelling hiervan. Waar die hoogste $d$-waarde by Oud (0.7) op 'n klein effek dui, is elkeen van hierdie van Jonk $(d>1.02)$ hoogs beduidend.

'n Post hoc-analise van die opnames van die enkele manlike spreker uit die 2017-groep van wie 'n voldoende hoeveelheid opnames vir ontleding beskikbaar was, is grootliks in ooreenstemming met dié van vroulike sprekers in die Jonk-groep. Sy $d$-waarde van 0.78 grens aan 'n hoogs beduidende effek.

Hierdie afdeling word met 'n nodige opmerking oor Skeefheid as spektrale moment afgesluit.

Hoewel op die gebruik van die spektrale moment Gravitasiemiddelpunt (CoG) besluit is op grond van die bewese kragtigheid daarvan in soortgelyke studies op ander tale, toon 'n post hoc-analise dat Skeefheid soortgelyke resultate oplewer by die vergelyking van die twee groepe se produksies van /s/ in die onderhawige fonetiese kontekste. Tabel 4 gee die basiese metings daarvan weer.

Die hoër $d$-waarde vir Jonk ondersteun die bevindings wat ten opsigte van CoG gekry is. Hoewel negatiewe waardes vir albei realisasies van /s / by Oud en by Jonk gevind word, beteken die groter afstand tussen [s]-en $[S]$ by Jonk $(d=0.90)$ 'n relatiewe hoër konsentrasie van energie in die spektrum van hierdie allofoon as wat die geval is by die Oud-groep.

\section{Bespreking}

In hierdie studie is dit uitgewys dat daar in die uitspraak van die groep nuuslesers van 2017 (Jonk) vergeleke met dié van 2000-2006 (Oud) 'n pertinente verskil is wat die fonetiese eienskappe van die foneem /s / in twee kontekste betref, naamlik met en sonder die teenwoordigheid van $/ \mathrm{r} /$, respektiewelik [S] en [s]. Jonk se CoG is sodanig verskillend $(d=0.90)$ dat dit as bevestigend geneem kan word vir die perseptuele indruk wat hierdie klanke maak. Op grond van hierdie gegewe behoort [S] wel hier as

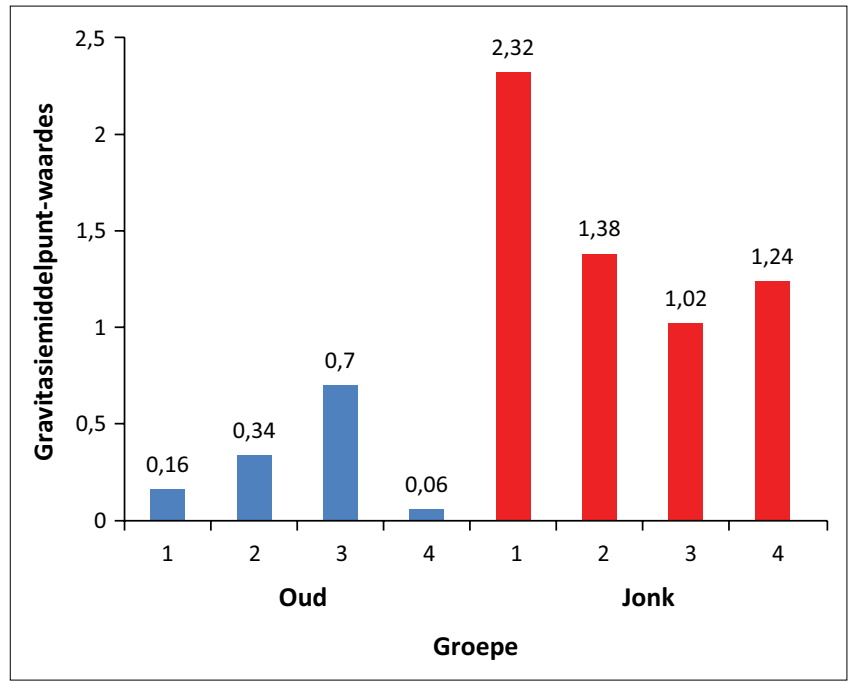

FIGUUR 5: Vergelyking van die individuele lesers van die twee groepe vroulike lesers, (a) oud en (b) jonk, se produksies van /s/.

TABEL 4: Vergelyking van die metings van die groepe lesers - Oud en Jonk - vir Skeefheid as spektrale moment.

\begin{tabular}{lccccc}
\hline Ouderdomskategorie & Frikatief & $\begin{array}{c}\text { Gem. } \\
\text { Skeefheid }\end{array}$ & $\begin{array}{c}\text { Gemete } \\
\text { gevalle }\end{array}$ & $\begin{array}{c}\text { Std.afw. } \\
\text { Skeefheid }\end{array}$ & $\boldsymbol{d}$-waardes \\
\hline Oud & {$\left[\int\right]$} & -0.54 & 231 & 0.55 & 0.25 \\
& {$[\mathrm{~s}]$} & -0.77 & 354 & 0.89 & - \\
Jonk & {$\left[\int\right]$} & -0.59 & 195 & 0.62 & 0.90 \\
& {$[\mathrm{~s}]$} & -1.15 & 191 & 0.82 & - \\
\hline
\end{tabular}

Gem., gemiddeld; Std. afw., standaardafwyking, CoG, gravitasiemiddelpunt.

allofoon van /s/ gekarakteriseer te word. Dit is ook in ooreenstemming met die gevestigde konvensie om die gepalataliseerde /s/ in gevalle soos in die frase is $j y$ met $\left[\int\right]-$ soos in [ə- $\int$ i $]$ - te transkribeer.

Die bevindings van hierdie ondersoek strook nie net met dié van Wissing et al. (2015) nie, maar is ook 'n bevestiging van uitgebreide ouditiewe waarnemings van die uitspraak van hedendaagse Afrikaans oor 'n wye spektrum: ${ }^{11}$ in algemene omgangstaal soos gehoor by jong sprekers soos studente en skoolleerders, in inbelprogramme, en soos hierbo reeds genoem is, veral jonger radiopersoonlikhede wat nie net nuusberigte lees nie, maar ook algemene aankondigings maak, weerberigte lees, en verder ook veral jonger predikers in kerkdiensuitsendings.

'n Verklaring vir hierdie moderne verskynsel is nie voor die hand liggend nie. Dit kan wel as 'n geval van progressiewe konsonantassimilasie getipeer word, maar die rede hiervoor is nie duidelik nie. Moontlike verklarings vanuit fonologiese raamwerke wat van klankverandering oor die algemeen getuig, word vanuit 'n produksie- of persepsieperspektief aangetref, metwisselendeklemopóf die produksie-,óf die persepsiefasette daarvan, óf 'n kombinasie daarvan. Ohala $(1981,1989,1993)$ stel 'n wanpersepsiemodel (Misperception Model) voor, wat 'n luisteraar-gebaseerde raamwerk is. Hy skryf die

11.'n Anonieme keurder spreek die kommer uit dat die gebruik van die omskrywing 'wye spektrum' waarskynlik te veralgemenend is. Die keurder is van mening dat hierdie verskynsel tot Gauteng en die Noordwes-Provinsie beperk mag wees; die persoon hoor dit nie in Kaapstad nie, ongeag die etnisiteit van die sprekers. Wat wel reeds gedokumenteer is, is die afwesigheid daarvan in die Afrikaans van bruin sprekers van die dorp Genadendal, wat as verteenwoordigend van ten minste die landelike gebiede van die Wes-Kaap geneem sou kon word (lees Wissing et al. 2015 hiervoor). 
inkongruensie tussen sprekers en hoorders toe aan 'n wanpersepsie aan die kant van die hoorder. Die variasieseleksiemodel van Lindblom et al. (1995) lê op die verskillende maniere van persepsie klem. Blevins (2004) sien die eerste fase van klankverandering as 'n proses waartydens akoestiese eienskappe weens perseptuele verwarring op foutiewe fonetiese representasies oorgedra word. Beddor (2009) se konseptuele model van die rol van die hoorders se rol in klankverandering betrek variasie in die persepsiegrammatika.

Wissing et al. (2015) sluit in 'n mate by Beddor (2009) se model aan. Hulle hou die volgende verklarings voor, soos basies deur Andries Coetzee (persoonlike mededeling) voorgestel, en brei daarop uit: 'n Moontlike verklaring van artikulatoriese aard kan wees dat die Afrikaanse /r/trilklank in hierdie fonologiese konteks refleksief van aard is, wat koartikulering van /s/ met die daaraan voorafgaande [r] dié frikatief moontlik maak in ooreenstemming met die refleksiewe palataalagtige $/ \mathrm{r} /$. Hierdie verklaring vereis 'n dieper ondersoek met behulp van 'n ultrasoniese aftaster na die werklike fonetiese realisasie van $/ \mathrm{r}$ / in hierdie kontekste ten einde te kan vasstel hoe dit presies geproduseer word: as alveolêre triller, as retrofleks, of selfs of dit weggelaat of gevokaliseer word. Die feit dat 'n palataalagtige [s] ook by nonpalataliseerders opgemerk word (sodanige sprekers vertoon wel oor die algemeen laer CoG-waardes vir [s]frikatiewe na $[\mathrm{r}])$, ondersteun so'n puur fonetiese verklaring. Hierdie verskil word dan om 'n onduidelike rede geamplifieer in die spraak van 'n aantal jonger sprekers. Dit is 'n bekende verskynsel dat so 'n neiging 'aansteeklik' werk, en in sommige gevalle selfs ongewoon vinnig versprei, aanvanklik veral onder portuurgroepe soos wat waarskynlik ook die geval is met die ronding van die Afrikaanse lang /a/-vokaal (vgl. Wissing 2006). Hoorders wat met sodanige matige vorm van koartikulasie gekonfronteer word, hanteer in hulle produksie van /s/ in hierdie geval deur die koartikulasie ongedaan te maak en wel deur 'n proses bekend as kompensasie-vir-koartikulasie. Hulle skryf dus die gehoorde palataalagtige eienskap van die uitspraak van /s/ toe aan [r], wat beteken dat die /s/ wel as alveolêre [s], en nie as [S] nie, ervaar word. Sodanige kompensatoriese proses word suksesvol in die geval van ouer sprekers voltrek, terwyl jongeres - wat dieselfde klank hoor - die oorsprong van die palatalisasie nie as /r/ ervaar nie, maar as 'n inherente eienskap van /s/ self. Daarom interpreteer hulle /s/ in werklikheid as [S] en nie as [s] nie; dit loop weer uit op hulle poging om die palatale frikatief [ $\left.\int\right]$ in die betrokke fonetiese konteks te produseer. Die resultaat hiervan is dat die jonger sprekers se [s]-klanke meer palataal van aard is as dié van die ouer taalgebruikers. Dat 'n mens van tyd tot tyd ook sodanige meer palatale /s/ by ouer sprekers hoor, kan toegeskryf word aan 'n poging van sulke sprekers om die uitspraak van jong sprekers na te maak, natuurlik onbewustelik. Hierby kan gespekuleer word dat sommige ouer sprekers meer sukses hiermee het, onder meer omdat hulle in hulle daaglikse omgang meer met jongmense te doene kry - tipies die geval met taalgebruikers in beroepe soos die onderwys.

\section{Erkenning}

Die gebruik van RSG-opnames word met dank erken.

\section{Mededingende belange}

Die outeur verklaar hiermee dat hy geen finansiële of persoonlike verbintenis het met enige party wat hom voordelig of nadelig kon beïnvloed het in die skryf van hierdie artikel nie.

\section{Literatuurverwysings}

Beddor, P.S., 2009, 'A coarticulatory path to sound change', Language 85(4), 785-821. https://doi.org/10.1353/lan.0.0165

Bekker, I., 2007, 'Fronted /s/ in general white South African English', Language Matters 38(1), 46-74. https://doi.org/10.1080/10228190701640025

Blevins, J., 2004, Evolutionary phonology: The emergence of sound patterns, Cambridge University Press, Cambridge.

Boersma, P. \& Weenink, D., 2015, Praat: Doing phonetics by computer, viewed 15 December 2015, from http://www.praat.org

Coetzee, A.E., 1981, Fonetiek vir eerstejaars, Academica, Pretoria.

Coetzee, A.E., 1992, Fonetiek, Academica, Pretoria.

Coetzee, A.W., Beddor, P., Shedden, K. \& Wissing, D., 2018, 'Plosive voicing in Afrikaans: Differential cue weighting and tonogenesis', Journal of Phonetics 66 185-216. https://doi.org/10.1016/j.wocn.2017.09.009

Cohen, J., 1988, Statistical power analysis for the behavioral sciences, Lawrence Earlbaum Associates, Hillsdale, NJ.

Combrink, J.G.H. \& De Stadler, L.G., 1987, Afrikaanse fonologie, MacMillan, Suid-Afrika.

Davel, M.H. \& Barnard, E., 2008, 'Pronunciation prediction with Default\&Refine', Computer Speech \& Language 22(4), 374-393. https://doi.org/10.1016/j. csl.2008.01.001

Davel, M.H. \& De Wet, F., 2010, 'Verifying pronunciation dictionaries using conflict analysis, in Proceedings of the Eleventh Annual Conference of the International Speech Communication Association. Interspeech, ISCA, Makuhari, Japan, 28-30 September 2010, pp. 1898-1901.

De Bruto, H.F. \& Wissing, D., 1974, Aspekte van 'n Afrikaanse T.G.G.-fonologie, McGraw-Hill, Johannesburg.

De Villiers, M., 1961, 'Daar is geen verskil tussen “-tjie" en "-kie" nie', Tydskrif vir Geesteswetenskappe 1(1), 54-58, Mrt.

De Villiers, M. \& Ponelis F.A., 1987, Afrikaanse klankleer, Tafelberg-Uitgewers, Kaapstad.

Jongman, A. Wayland, R. \& Wong, S., 2000, 'Acoustic characteristics of English fricatives', Journal of the Acoustic Society of America 108(3), 1252-1263.

Kwakkel, V., 2008, 'Sibilants in Dutch and English: Typologies, learning tasks and language change', M.A. dissertation, University of Utrecht, Utrecht, the Netherlands.

Labov, W., 2001, Principles of linguistic change, vol. 2: Social factors, Blackwell, Oxford.

Le Roux, T.H. \& Pienaar, P. de V., 1927, Afrikaanse fonetiek, Juta, Kaapstad.

Lindblom, B., Guion, S., Hura, S., Moon, S.-J. \& Willerman, R., 1995, 'Is sound change adaptive?' Rivista di Linguistica 7, 5-37.

Ohala, J.J., 1981, 'The listener as a source of sound change', in C.S. Masek, R.A. Hendrick \& M.F. Miller (eds.), Papers from The 17th Regional Meeting of the Chicago Linguistics Society: Parasession on Language and Behavior, pp. 178-203, Chicago Linguistics Society, Chicago, IL.

Ohala, J.J., 1989, 'Sound change is drawn from a pool of synchronic variation', in L.E. Breivik \& E.H. Jahr (eds.), Trends in linguistics, studies and monographs language change: No. 43, Contributions to the study of its causes, pp. 173-198, Mouton de Gruyter, Berlin.

Ohala, J.J., 1993, 'The phonetics of sound change', in C. Jones (ed.), Historical linguistics: Problems and perspectives, pp. 237-278, Longman, London.

Van Niekerk, D.R. \& Barnard, E., 2009, 'Phonetic alignment for speech synthesis in under-resourced languages', in Proceedings of the Tenth Annual Conference of the International Speech Communication Association. Interspeech, ISCA, Brighton, UK, 8-10 September 2009, pp. 880-883.

Wissing, D., 1982, Algemene en Afrikaanse generatiewe fonologie, Macmillan, Johannesburg.

Wissing, D., 2017, 'Fonetiek', in W.A.M. Carstens \& N. Bosman (reds.), Kontemporêre Afrikaanse Taalkunde, bl. 151, Van Schaik, Pretoria.

Wissing, D., Pienaar, W. \& Van Niekerk, D., 2015, 'Palatalisation of /s/ in Afrikaans', Stellenbosch Papers in Linguistics Plus 48,137-158. https://doi.org/10.5842/ 48-0-688

Wissing, D.P., 1971, Fonologie en morfologie van die simplekse selfstandige naamwoord in Afrikaans: 'n Transformasioneel-generatiewe beskrywing, Buijten \& Schipperheijn, Amsterdam.

Wissing, D.P., 1984, Algemene en Afrikaanse generatiewe fonologie, MacMillan, Johannesburg. 